\title{
OF SAVAGERY AND CIVIL SOCIETY: PIERRE CLASTRES AND THE TRANSFORMATION OF FRENCH POLITICAL THOUGHT ${ }^{\star}$
}

\author{
SAMUEL MOYN
}

Department of History, Columbia University

This essay examines the thought of the French anthropologist Pierre Clastres (19381977). It situates his once-famous depiction of savage politics as a premonitory rejection of the state at the crossroads of several traditions, long-and short-term. First, Clastres's thought resonates with the primitivistic appeal by French "moralists" since the early modern period to the lifestyle of prehistoric societies; second, it casts light on the history of French anthropology in the crisis years of structuralism; and third, it reflects the revival of Friedrich Nietzsche in French thought of the era. Above all, however, the essay explains Clastres's thought as an attempt to resist and to overcome the well-known communist allegiances of postwar French intellectuals. Early in rejecting communism, Clastres owed his prominence to the 1970s popularization of the critique of "totalitarianism." The so-called "passing of an illusion" of communism, one version of which Clastres pioneered, is often interpreted as the replacement of confusion with truth. It is more interesting, the essay suggests, to situate it in its time, as a complex achievement as defective as it was creative, if Clastres's thought is taken as an example. In closing, the essay suggests some legacies, often unintentional, Clastres left behind in French political thought of the years since his death.

Someone said to Socrates that a certain man had grown no better in his travels. "I should think not," he said. "He took himself along with him."

Michel de Montaigne

Born in 1934, the French anthropologist Pierre Clastres died in a car accident in July 1977. He was at the height of his influence in France, even, for some, a new

I am grateful to Peter Hubbard for research assistance, and to Robert Hamrick for advice.

1 Montaigne is cited in P. Clastres, “Copernic et les Sauvages," Critique 270 (1969), 1000-15, rptd as Clastres, La Société contre l'État: Recherches d'anthropologie politique (Paris, 1974), chap. 1, and in English as Clastres, Society against the State: Essays in Political Anthropology, trans. R. Hurley and A. Stein (New York, 1987), 7. 
guru. Neglected by intellectual historians, Clastres stood at the intersection of a number of developments in postwar French thought: the disciplinary history of ethnography in the crisis years of structuralism; the longer tradition of the literary essayist and moralist, in which primitive "others" often served as a privileged means for thinking about French modernity; the reception of Friedrich Nietzsche in the years in which postmodernism came into fashion; the creative ferment, among intellectuals, of the years following the 1968 events. But Clastres's chief significance is political: he reflected, and furthered, the decomposition of Marxism among French intellectuals and the search for alternatives to it, and showed what creative and consequential forms the "passing of an illusion" could take. This intellectual and political nonconformist, who wrote moving elegies to disappearing societies with no state, and rhetorically searing criticisms of expanding societies that displaced them, played a memorable role in the transformation of French political thought in the period, helping it to transcend, once and apparently for all, the intellectual framework that had dominated it for so long. His influence lies beyond the scope of this essay. But the fact that Clastres inadvertently contributed not simply to a new kind of left-wing political theory influential to this day but also to the foundations of neo-liberalism in French thought makes a foray into his worldview - a reconstruction of its details-even more interesting and worthwhile. That quite despite his intentions Clastres could have helped secure some of the conditions for the unexpected victory in French political theory of the very modernity that he despised is no doubt the greatest irony about his endeavor, and the chief reason for studying it.

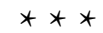

G. W. F. Hegel famously claimed that "the State is the precise object of world history in general." He acknowledged that "[a] people may have lived a long life without having arrived at their destination by becoming a state," but consigned this "long life" to the status of "prehistory" which lies "entirely outside of [the] concern" of the philosophy of history "no matter whether a genuine history comes after it, or the people involved never arrived at the formation of a state." Jean-Jacques Rousseau, with his attractive but misguided idealization of the noble savage, had badly erred in rooting freedom in the primitive state of humankind. "One can certainly point to the existence of savage conditions," Hegel observed, "but these are shown to be linked to the passions, to barbarism, and acts of violence." Freedom finding no purchase in savagery, except as "implicit destiny ... to be fulfilled," social discipline, perfected by the state, is required for history to begin. ${ }^{2}$ Few commentators would now take seriously the notion that 
Hegel - who also made a decisive contribution to the theory of civil societylaid the groundwork for the totalitarian state, inventing a dialectic of history that, perfected by Marxism, communism, and Stalinism, left no destination but the gulag. It was several French intellectuals, bitterly disappointed by their youthful political engagement, whose brief influence nonetheless played on and further purveyed this assumption. Only Clastres, however, popularized the notion logically following from this line of thought, that the primitive world that Hegel had forgotten might provide the sole possible alternative to the perilous epitome of history.

Eventually a furious critic of all theories of progress, Clastres began as a communist; faced with the crisis of 1956, however, he searched for an alternative point of view. Initially a student of philosophy, steeped in the texts of Friedrich Nietzsche and Martin Heidegger, which were to be a permanent influence on him, Clastres became an anthropologist. The chance for literary achievement that ethnological reportage offered, on the model of Claude Lévi-Strauss's Tristes Tropiques, also pushed Clastres into the career he would make for himself. But like several others in the aftermath of 1956, structuralism had a mainly political allure. Structuralist anthropology provided many, in the later 1950s, with the sequel to communism, with the Soviet tragedy often (fairly or unfairly) understood to be rooted not in the contingencies of history but rather in the constitutive defects not simply of Marxism but of progressivist modernity as a whole. Structuralist anthropology discovered "cold" societies before the existence of the hot and historical ones that had given rise to communist horror; in a certain sense, then, it provided a point of view external to the dialectic. "They aspired to find something more profound than exoticism," François Dosse comments in his History of Structuralism of Clastres and other converts to Lévi-Strauss's anthropology; "for them, it was a matter of locating societies that had been sheltered from the unitary map of Hegelian Marxist thinking, societies that were not classified in Stalinist handbooks." 3 Having, in a sense, found the end of history in the Stalinist dictatorship, Clastres and his fellow ex-communists transmuted their earlier idealism by seeking an alternative to Stalinism before universal history's beginning.

The following will argue that Clastres-like those affected by his thoughtproved to be so haunted by the "Hegelianism" he hoped to leave behind that it

3 F. Dosse, History of Structuralism, trans. D. Glassman, vol. 1, The Rising Sign, 1945-1966 (Minneapolis, 1997), 162. Dosse, who reports Clastres's love and admiration for Tristes Tropiques in particular, is referring to Clastres and several others close to him-Alfred Adler, Michel Cartry, and Lucien Sebag-who became anthropologists as a result of the 1956 events. A decade later, of course, some like Louis Althusser explored the compatibility of Marxism and structuralism, a possibility which some original converts extended to anthropology. See, for example, Sebag, Marxisme et structuralisme (Paris, 1964). 
followed him wherever he went. If so, it would make of Clastres an exemplification of an old story: hoping to find an extra-European point of view on European society, he made up at home those whom he claimed to discover someplace else. And yet Claude Lefort, Clastres's associate, claimed instead that his friend "bore within himself the figure of the other.... It would be futile to suspect that he either could or would see only what fit his expectations. When one is reading him, one marvels, on the contrary, at an encounter with the other that was prefigured in himself." Similarly, one of Clastres's companions in the move from communism to structuralism went so far at a memorial for his old friend as to suggest that, though this youthful transition counted as the secret and barely suppressed drama of his career, it enabled him to discover an enduring truth not simply about primitive society but about his own as well: "Pierre Clastres's voice fell silent too brusquely on the genealogy of a project born in the context of an age in which the 'adventures of the dialectic' had led to the impasses and insanities that are well-known," he suggested. "No one will explain as he could have the origins of a quest intended to find in the faraway what, right at home, the dialectic had totally forgotten..." 4

In fact, Clastres wrote his first, and possibly most important, analysis of South American Indians before ever visiting them. Having trained under Lévi-Strauss, himself a specialist in the Nambikwara and other South American tribes, having read voraciously in early travel literature, and having absorbed the ethnography of the US State Department-sponsored Handbook of South American Indians, Clastres presented his major insight into the political significance of Indian chieftainship in his first published article in $1962 .{ }^{5}$ No doubt experience on the scene of the Indian chiefs who interested him added to and provided depth and extension to his original argument-and indeed, it allowed him to reject armchair critics who had experienced no similar immersion in another societybut the simple fact that he offered his hypothesis before and independent of its

C. Lefort, "Pierre Clastres," Libre 4 (1978), 51; M. Cartry, "Pierre Clastres," Annuaire de la $V^{e}$ Section de l'École des Hautes Études 85 (1978), rptd in ibid., 39-40. Lefort repeated his judgment in “L'œuvre de Clastres," in M. Abensour, ed., L'esprit des lois sauvages: Pierre Clastres ou une nouvelle anthropologie politique (Paris, 1987), rptd as "Dialogue avec Pierre Clastres," in Lefort, Écrire: À l'épreuve du politique (Paris, 1992), and in English in Lefort, Writing: The Political Test, trans. D. A. Curtis (Durham, NC, 2000), 208.

5 Clastres, "Échange et pouvoir: philosophie de la chefferie indienne," L'Homme 2/1 (1962), 51-65, rptd as Clastres, La Société contre l'État, chap. 2, in English in Clastres, Society against the State, in J. H. Steward, ed., Handbook of South American Indians, 7 vols. (Washington, D.C., 1946-59). 
experiential confirmation is of obvious significance. As he later acknowledged with pride in an interview, he did not waver from theory to theory as others change their clothes. ${ }^{6}$ He offered a single argument, and stuck to it until his death.

Clastres began his analysis with some curious and refractory ethnographic data about the nature of chieftancy in primitive society, especially American Indian society (and, more specifically, among the tropical forest cultures of South America that had escaped the orbit of the Incan imperial experience). The facts, he put it, were well known; his essay intended to explain their meaning. Put simply, Indian chieftains had no power, and indeed were elevated only on condition of disempowerment. According to Clastres, the chief stood for peace and reconciliation within the tribe. Moreover, he acted with faultless generosity: he owed what Clastres often called an "infinite debt" to his society. Except in the case of war, he could command only by means of what a later philosopher would call the "unforced force" of speech; great oratorical skills were normally the major qualification for the office. In addition, in South America, the chief very often enjoyed exclusive right to multiple wives.

For Clastres, this constellation of attributes took on new significance when one realized that the role of speech, the transfer of goods, and the rules of kinship amounted to the major domains of the constitution of society itself. "It is extraordinary to discover," he wrote,

that this trinity of predicates-oratorical talent, generosity, and polygyny-attached to the person of the leader, concerns the same elements whose exchange and circulation constitute society as such and sanctions the transition from nature to culture.... Hence, power relates here ... to the three essential structural levels of society; that is, it is at the very heart of the communicative universe. ${ }^{7}$

Somehow the shape of power bore a necessary relationship to the fundamental constitution of society. The key to the understanding of each domain, Clastres continued, is that in each the chief enjoys a one-way relationship with his own society. While he appeared to trade goods and words for wives, he actually gave and received each independently, each a bargain without consideration. Assuming that society is constituted by exchange, then the office of power is placed outside of the social realm. "This triple movement [of women, gifts, and oratory] manifests a common negative dimension which assigns these three types of 'signs' an identical fate: they no longer appear as exchange values, reciprocity ceases to regulate their circulation," Clastres wrote.

6 In his original argument, Clastres remarked, “je n'ai pas grand'chose à y changer. On ne peut pas m'accuser de changer d'idées comme des chemises!" "Entretien avec Pierre Clastres," L'Anti-mythes 9 (1975), 21. 
Hence a new relationship between the domain of power and the essence of the group comes to light: power enjoys a privileged relationship toward those elements whose reciprocal movement founds the very structure of society. But this relationship, by denying these elements an exchange value at the group level, institutes the political sphere not only as external to the structure of the group, but further still, as negating that structure: power is contrary to the group, and the rejection of reciprocity, as the ontological dimension of society, is the rejection of society itself. ${ }^{8}$

Put differently, the role primitive societies scripted for the chief bespoke a philosophy of the place and function of power. They constituted power as external to society-indeed, as what society by definition excluded even in constituting it. In Clastres's slogan, primitive societies were societies against the state.

This effect, which Clastres believed explained the oddity of empowered yet powerless chieftancy in primitive society, he regarded as no accident or aberration. There is, he maintained, "a certain necessity inherent in the process itself," which only came into view at the level of "sociological intentionality." As he put it, "[P] ower is exactly what these societies intended it to be." So

far from giving us the lackluster image of an inability to resolve the question of political power, these societies astonish us by the subtlety with which they have posed and settled the question. They had a very early premonition that power's transcendence conceals a mortal risk for the group, that the principle of an authority which is external and the creator of its own legality is a challenge to culture itself. It is the intuition of this threat that determines the depth of their political philosophy ... They chose themselves to be the founders of ... authority, but in such a manner as to let power appear only as a negativity that is immediately subdued, [and] strip[ped] of any real might. Thus, the advent of power, such as it is, presents itself to these societies as the very means for nullifying that power. $^{10}$

They possessed a sense of the dialectic's catastrophic ending, and, out of their "sense of democracy and taste for equality," took steps, intentional if perhaps unconscious, to avoid its beginning. ${ }^{11}$ In this sense, they were not just without a state, but societies against it - and a monitory signal from the primitive world that moderns could recover in their own state of suffering.

8 Ibid., 41-2. For a related analysis of the chieftain's oratory, see Clastres, "Le devoir de parole," Nouvelle Revue de psychanalyse 8 (1973), 83-5, rptd as La Société contre L'État, chap. 7 .

9 Ibid., 43.

10 Ibid., 44-5.

11 Ibid., 28. 
Inspired by the prospect of further study of societies that achieved modes of power that ruled a Stalinist conclusion out in advance-and apparently by premonitory design-Clastres spent much of the 1960 s either working at Lévi-Strauss's Laboratoire d'anthropologie sociale or in South America doing "fieldwork." His first mission, an eight-month trip in 1963 to the Paraguayan tribe of the Guayaki, previously among the most isolated and least researched remaining forest cultures, gave rise to Clastres's thesis and, later, to his remarkable Chronicle of the Guayaki Indians. ${ }^{12}$ Clastres chose the Guayaki (or Aché) because they had been so mysterious, until some members of the tribe were located and restricted to a territorial reservation and a pacifying campaign between 1959 and 1962. Much like Tristes Tropiques, Clastres's ethnographic masterpiece won many admirers for its literary qualities; among those enchanted by it, the future novelist Paul Auster, then an American in Paris living from hand to mouth on translation work, found it so moving that he produced an Englishlanguage version. "Clastres's prose," Auster recalled, "seemed to combine a poet's temperament with a philosopher's depth of mind... It is, I believe, nearly impossible not to love this book."13 Clastres studied his subjects on a ranch-cum-reservation where they had fallen under the government-approved supervision of a "friendly" Paraguayan farmer; on this point Clastres ruefully cited Alfred Métraux, the French anthropologist who had helped arrange his sojourn: "For us to be able to study a primitive society, it must already be starting to disintegrate." ${ }^{14}$ In 1965, Clastres returned to Paraguay, initially intending to "fulfill the secret desire of every Americanist anthropologist: to be the first to encounter savage Indians." But in spite of trying, he failed to locate the last Guayaki who had eluded the Paraguayan government's pacification campaign. ${ }^{15}$ They did not remain undiscovered for long; indeed, Clastres's Chronicle almost

12 Clastres and Sebag, "Cannibalisme et mort chez les Guayaki," Revista do Museu Paulista 14 (1963), 174-81; Clastres, "Compte-rendu de mission chez les indiens Guayaki (Paraguay)," L'Homme 4/2 (1964), 122-5; Clastres, La Vie sociale d'une tribu nomade: les indiens Guayaki du Paraguay (thèse du $3^{\mathrm{e}}$ cycle; Paris, 1965); Clastres, "Ethnologie des indiens Guayaki: La vie sociale de la tribu," L'Homme 7/4 (1967), 101-8; Clastres, "Ethnographie des indiens Guayaki," Journal de la société des américanistes 57 (1968), 9-61; Clastres, "The Guayaki," in M. G. Bicchieri, ed., Hunters and Gatherers Today: A Socioeconomic Study of Eleven Such Cultures in the Twentieth Century (New York, 1972); Clastres, Chronique des indiens Guayaki: Ce que savent les Aché, chasseurs nomades du Paraguay (Paris, 1972).

13 Clastres, Chronicle of the Guayaki Indians, trans. P. Auster (New York, 2000), 7-8. As Auster recounts in his foreword, while he produced the translation in the 1970s, it only recently appeared after the publisher balked and the sole manuscript disappeared.

14 Ibid., 96.

15 Clastres, "Mission au Paraguay et au Brésil," L’Homme 7/4 (1967), 101-8, at 101. 
immediately became the Guayaki's obituary: massacres by Alfredo Stroessner's Paraguayan government in the early 1970 s decimated them. ${ }^{16}$ In the later 1960 s and very briefly in the early 1970s, Clastres spent time among the Guarani, also in Paraguay, and recorded examples of their eloquent paeans to their gods, later the basis of his study The Great Speech: Myths and Sacred Chants of the Guarani Indians of $1974 .{ }^{17}$ Clastres's last major research experiences in South America occurred in 1966 and 1968, when he visited the Chulupi Indians in Paraguay, eventually intending to base studies of mythology and warfare on the information he gathered. ${ }^{18}$ Aside from a period among the Yanomani Indians of Brazil, with his friend Jacques Lizot, Clastres spent most of the 1970s in Paris, teaching at the École Pratique des Hautes Études ( $\mathrm{V}^{\mathrm{e}}$ section), until his untimely death.

Clastres's initial essay, before these on-site investigations, exhibited a vestigial structuralism, notably in his analysis of the exchange involved between the society and the chief. His argument, reminiscent of his mentor's thinking, relied on a rejection of the diachronic (for example, the fact that in exchange for multiple wives the chief returned his daughters to the next generation). It also avoided "superficial" aspects of the synchronic, for example the notion that the chief reciprocally exchanged pacifying words for multiple women, on the grounds that only through separation and comparison of elements in the exchange could their relation to the deep structure of society come into view. On his return from South America, in the series of essays that were collected in his signature work Society against the State (1974), Clastres dropped any allegiance to structuralism. His esteem for Lévi-Strauss remained high, as his contribution to his teacher's Festschrift shows, and he continued to insist on the viability of

See M. Münzel, The Aché Indians: Genocide in Paraguay (Copenhagen, 1973), R. Arens, ed., Genocide in Paraguay (Philadelphia, 1976), and E. Wiesel, "Accomplices," in A Jew Today, trans. M. Wiesel (New York, 1978); but cf. D. Maybury-Lewis and J. Howe, The Indian Peoples of Paraguay: Their Plight and Their Prospects (Cambridge, MA, 1980), 35-50, for a more skeptical view on reports of genocide.

17 Clastres, Le Grand Parler: Mythes et chants sacrés des indiens Guarani (Paris, 1974). Clastres owed his introduction to the Guarani and help in translating his ethnographic material to Léon Cadogan, a Paraguayan anthropologist and activist, who had earlier assisted him with the Guayaki. Cf. Clastres, Chronicle of the Guayaki Indians, 76-7, and Clastres, "Léon Cadogan," L'Homme 14/2 (1974), 135-6.

18 On war, see Clastres, "L’archéologie de la violence: la guerre dans les sociétés primitives," Libre 1 (1977), 137-73, and Clastres, "Malheur du guerrier sauvage," Libre 2 (1977), 69109, both rptd in Clastres, Recherches d'anthropologie politique (Paris, 1980), chaps. 11-12, in English in Clastres, The Archeology of Violence, trans. J. Herman (New York, 1994). More recently, this first essay has been republished on its own as Clastres, L'archéologie de la violence: la guerre dans les sociétés primitives (Paris, 1998). On mythology, see the posthumous Clastres, Mythologie des Indiens Chulupi, ed. M. Cartry and H. Clastres (Louvain, 1993). 
structural analysis on Lévi-Strauss's chosen terrain of myth. ${ }^{19}$ But in his mature works, he moved on to become the foremost scholar in the emergence of the new subdiscipline of "political anthropology." 20 As structuralism entered its crisis phase in the later 1960 s and Marxist anthropology became a disciplinary alternative to structuralism-or, as in Maurice Godelier's conciliatory proposal, came to its rescue-Clastres presented his own "political anthropology" as the more plausible sequel or complement to structuralist analysis. It was true, Clastres acknowledged, structuralism had never overcome a constitutional debility, the avoidance of the topic of the political constitution of primitive society. LéviStrauss had achieved heroic victories in the understanding of kinship and myth, yet his analyses had somehow stopped short of the object of social study: society itself. The limit of the structuralist analysis of kinship, Clastres noted, is that it leaves analysis "at the threshold. The primitive social body cannot be reduced to its blood ties and alliances; it is not only a machine for fabricating kinship relations." As for Lévi-Strauss's procedure of understanding myth, it "is only operative on the condition of cutting the myths from society, of seizing them, ethereal, floating a good distance from the space of origin." For this reason, anthropologists were correct to search for a remedy to structuralism's “absence: this elegant discourse, often very rich, does not speak about the society. It is . . like a godless theology: it is a sociology without society." ${ }^{21}$ But this fact did not make Marxist anthropology inevitable, as others began to urge. ${ }^{22}$ It actually cleared the way, Clastres thought, for his own political anthropology.

19 According to Clifford Geertz, Lévi-Strauss considered Clastres his successor. Geertz, "Deep Hanging Out" (review of Clastres, Chronicle of the Guayaki Indians), New York Review of Books, October 22, 1998. But in the mid-1970s their relations became strained. Clastres, "Entre le silence et le dialogue," L'Arc (1968), 76-8, rptd in R. Bellour and C. Clément, Claude Lévi-Strauss: Textes de et sur Claude Lévi-Strauss (Paris, 1979).

20 On the lineages of "political anthropology" before it became closely identified with Clastres's work, see G. Balandier, Anthropologie politique (Paris, 1967, 1969), esp. chap. 1, in English as Political Anthropology, trans. A. M. Sheridan-Smith (New York, 1970). In particular, British Africanists had advanced the field just after World War II, not excluding the perception of a unique, "stateless" politics. See, for example, J. Middleton, ed., Tribes Without Rulers: Studies in African Segmentary Systems (London, 1958).

21 Clastres, "Les Marxistes et leur anthropologie," Libre 3 (1978), 135-49, rptd in Recherches d'anthropologie politique, chap. 10, in English in Clastres, The Archeology of Violence, 128-30.

22 For a general portrait of the crisis of structuralism in French anthropology and the incursion of Marxism as a respectable position in the discipline, see Dosse, History of Structuralism, vol. 2, The Sign Sets, 1967-Present (Minneapolis, 1997), chaps. 8, 16, and 36. Many of those who had initially defected to anthropology as an ideological replacement for their earlier Marxism, like Clastres and Alfred Adler, were among the most hostile critics of the incursion of Marxism into anthropology itself a decade later. 
According to one of Clastres's most remarkable essays, dating from 1969, political anthropology required a "Copernican revolution" in the discipline. Reviewing a work of a rival political anthropologist who had begun with Max Weber's definition of power as the state-based monopoly on legitimate violence, from which it followed that primitive societies were societies without power, Clastres responded that anthropology had to test, rather than assume, this result: "the point is that it is necessary to ascertain and verify on the terrain involvedthat of archaic societies-whether, when there is neither coercion nor violence, it is impossible to speak of power." ${ }^{23}$ Clastres, of course, had already done so. He knew of "a vast constellation of societies in which the holders of what elsewhere would be called power are actually without power." ${ }^{24}$ Clastres insisted now, in a new specification of his original theory, that the major distinction between primitive and modern societies consisted not in whether they had power but in whether this power took coercive form. Nevertheless, Clastres always defined savagery on the basis of what it would not become.

Clastres believed that his discovery changed the way power had to be understood, not just in its archaic but also in its state-based forms. Failing to find a state, many political anthropologists, Clastres charged, had located power everywhere and nowhere, in the webs of coercive norms of Emile Durkheim's conscience collective. This assumption, Clastres argued, forced a "gradual dissolution of the political." ${ }^{25}$ Anthropologists insisted on the alternative that power permeated everything — and hence became nothing — unless it were made state-based because they could not part with their Western prejudices. "[T] he model to which political power is referred and the unit by which it is measured," Clastres argued, "are constituted in advance by the idea Western civilization has shaped and developed. From its beginnings our culture has conceived of political power in terms of hierarchized and authoritarian relations of command and obedience." ${ }^{26}$ To see the originality and distinction of the savage definition of power, Western anthropologists would have to make a reversal of assumptions equivalent to the replacement of geo- by heliocentrism: "A Copernican revolution is at stake," Clastres wrote,

in the sense that in some respects, ethnology until now has let primitive cultures revolve around Western civilization in a centripetal motion, so to speak. Political anthropology

23 Clastres, "Copernic et les sauvages," 11. The article is a review of J.-W. Lapierre, Essai sur le fondement du pouvoir politique (Gap, 1968). Lapierre carried on a running debate with Clastres throughout the next decade. See Lapierre, "Sociétés sauvages, sociétés contre l'État," Esprit 44/5 (1976), 983-1001, and Lapierre, Vivre sans État?: Essai sur le pouvoir politique et l'innovation sociale (Paris, 1977).

24 Clastres, "Copernic et les sauvages," 11.

25 Ibid., 19.

26 Ibid., 16. 
appears to have made it abundantly clear that a complete reversal of perspectives is necessary... Political anthropology encounters a limit that is not so much a property of primitive societies as it is something carried within anthropology itself, the limitation of the West itself, whose seal is still engraved upon it. In order to escape the attraction of its native earth and attain real freedom of thought, in order to pull itself away from the facts of natural history in which it continues to flounder, reflection on power must effect a "heliocentric" conversion: it will then perhaps succeed in better understanding the world of others, and consequently our own.

Much of Clastres's rhetoric, notably in this essay, betrayed the power of Nietzsche's vision in France at this time. Nietzsche, after all, had condemned the "new idol" of the state, "the coldest of all monsters." "This is the lie that calls from its mouth: I, the state, am the people." And, though he refused his sister's invitation to travel to Paraguay where she and her husband founded an Aryan colony, Nietzsche often understood himself as a seafarer who had-philosophically at least_-visited the Antipodes and lived under the light of different climes. "[T]he almighty force of our tasks," Nietzsche explained, "drove us apart again into different seas and sunny zones, and . . . our exposure to different seas and suns has changed us." ${ }^{\prime 2}$ It must have been in allusion to Nietzsche's own Copernican practices that Clastres likewise concluded: "It is time to change suns." 28

\section{$\star * *$}

The timing for Clastres's primitivist reversal of thinking about power and rejection of the state was extraordinarily propitious, and only an unexpected convergence of trends explains his brief moment of popularity and prominence in the 1970s. The effect of May 1968 on French intellectual life, still in the process of analysis by historians, pointed overwhelmingly in the direction of a post-centralized, non-hierarchical, pluralistic, and above all participatory vision of politics - one in many respects never successful in discovering institutional mechanisms for its own realization. This vision both followed from and further promoted the ongoing rejection of Hegelian Marxism, above all its ne plus ultra in what Clastres called in his Copernicus essay "its ultimate form: the centralized

27 The Nietzsche citations are from Thus Spake Zarathustra, Part I, chap. 11, and The Gay Science, $\S 282$. On Nietzsche and the sea, the best treatment is K. Harries, "Nietzsche at Sea," in M. A. Gillespie and T. B. Strong, eds., Nietzsche's New Seas: Explorations in Philosophy, Aesthetics, and Politics (Chicago, 1988); and on his solar rhetoric, see B. Pautrat, Versions du soleil: figures et système de Nietzsche (Paris, 1971). On "Neuva Germania," the Aryan colony founded by Nietzsche's sister and her husband, Bernhard Förster, see B. Macintyre, Forgotten Fatherland: The Search for Elisabeth Nietzsche (New York, 1992). 
state." ${ }^{29}$ Whether or not the South American forest people from time immemorial were contre l'État, Parisian intellectuals in the 1970s were: to the point that a whole generation, beginning on the left, and through drift and appropriation on the center and right, came to believe that the new point of departure for democratic political thought had to be the rejection of "the totalitarian state," and sometimes "the state" tout court. ${ }^{30}$ Of course, historically France pioneered not just state centralization but also the fear of it - as Alexis de Tocqueville's thought suggests - but only the political trends of 1968 explain why the fear became so great in the 1970 and why it became so appealing on the left. Not surprisingly, thinkers who had long since rejected communism as the institutionalization of freedom and insisted on the necessity of a pluralized and vibrant society outside the state, like Clastres, ascended to stardom.

Clastres's auvre in the years of his apotheosis consisted essentially of rich, eloquent essays. One could say, generalizing about them, that Clastres pursued and elaborated on his early thesis about power by delineating the stark contrast between the two worlds-primitive and modern-in which the political took such different forms. Troublingly, the series added up to an apparently primitivistic worldview that, as in Rousseau's Discourse on the Origins of Inequality, lamented the hell of modernity into which the observer's own culture had fallen.

In this vein, Clastres presented as some of his most important evidence the savage adoration for the power of language and their refusal of the endless production of desire (and endless work) he considered to be characteristic of the modern economy. The first of these themes reflected Clastres's involvement with Heidegger's philosophy as a young man, ${ }^{31}$ while the second found greatest expression in Clastres's championing of the work of the American anthropologist Marshall Sahlins..$^{32}$ But in burnishing the egalitarian, non-hierarchical credentials

\footnotetext{
29 Ibid., 25.

30 For a positive reading of this development, see D. Howard, The Specter of Democracy (New York, 2002), Part I; for a negative one, see M. S. Christofferson, French Intellectuals against the Left: The Anti-Totalitarian Moment of the 1970 (New York, 2004); in between, see A. Jainchill and S. Moyn, "French Democracy between Totalitarianism and Solidarity: Pierre Rosanvallon and Revisionist Historiography," Journal of Modern History 76/1 (2004), $107-54$.

31 See esp. Clastres, "L'arc et le panier," L'Homme 6/2 (1966), 13-31, rptd in Société contre l'Etat, chap. 5, and in English in Society against the State; cf. "Entretien avec Pierre Clastres," 20-21.

32 M. Sahlins, "La première société d'abondance," Les Temps modernes 268 (1968), 641-80; Sahlins, Stone-Age Economics (New York, 1972); Sahlins, Âge de pierre, âge d'abondance: l'économie des sociétés primitives, pref. Clastres, trans. T. Jolas (Paris, 1976). Clastres's preface is rptd as "L'Économie primitive," in Recherches d'anthropologie politique, chap. 8, and in English in The Archeology of Violence.
} 
of savage men, Clastres eventually had to confront the apparently prominent role of violence in their worlds. He adopted a surprisingly powerful strategy: to reinterpret the violence in primitive society as internal and essential to its selfimmunization against the rise of the state, and to compare it favorably to the grandiose horrors of the statist, modern world.

In this regard, there is no more provocative essay in Clastres's corpus than his discussion of primitive torture. ${ }^{33}$ Beginning with Franz Kafka, whose "In the Penal Colony" had understood that the body is an apt place for social law to be inscribed, as an indelible medium for and inescapable reminder of society's power, Clastres immediately moved to the then recently published testimony of Anatolii Marchenko. This Soviet prisoner's experience of living with penal tattoos like "Khrushchev's Slaves," Clastres suggested, illustrated the power of "the triple alliance, intuited by Kafka, between the law, writing and the body." Nevertheless, "there is something in the reality of the camps of the U.S.S.R. that surpasses even the fiction of the penal colony." 34

Primitive societies apparently undertake, typically as part of rites of passage, and thus as a universal rather than a penal event, the same inscription on the flesh which Clastres did not hesitate to call "torture," and, indeed, his Chronicle of the Guayaki Indians contains a gripping narrative of one such episode. ${ }^{35}$ As Clastres insisted, many societies preferred inflicting this ritual branding with the most painful possible methods, as a test of courage (as well as a frequent test of the anthropological observers whose morality it offended). And yet, Clastres continued, the ritual violence inflicted had a critical political function in these societies without a state:

The law they come to know in pain is the law of primitive society, which says to everyone: You are worth no more than anyone else; you are worth no less than anyone else. The law, inscribed on bodies, expresses primitive society's refusal to run the risk of division, the risk of a power separate from society itself, a power that would escape its control. Primitive law, cruelly taught, is a prohibition of inequality that each person will remember. ${ }^{36}$

The analogy of primitive and statist cruelty is, for this reason, false. Appealing to Gilles Deleuze and Félix Guattari's "brilliant" distinction in their Anti-Oedipus

33 Clastres, "De la torture dans les sociétés primitives," L'Homme 13/3 (1973), 114-20, rptd as La Société contre l'État, chap. 10, and in English in Society against the State.

34 Clastres, "De la torture dans les sociétés primitives," 179, citing A. Marchenko, Mon témoignage, trans. François Oliver (Paris, 1971). This book had appeared two years earlier in the United States as My Testimony (New York, 1969); cf. Clastres, "Martchenko," Textures 10-11 (1975), 45-6.

35 Clastres, Chronique des indiens Guayaki, chap. 4.

36 Clastres, "De la torture dans les sociétés primitives," 186. 
(published the year before this essay) between marking and writing, Clastres suggested that in fact primitive "marking" prevented the rise of the state, and $a$ fortiori the possibility of modern "writing" that Anatolii Marchenko had suffered in totalitarian circumstances. ${ }^{37}$ "It is proof of their admirable depth of mind," Clastres wrote, "that the Savages knew all that ahead of time, and took care, at the cost of a terrible cruelty, to prevent the advent of a more terrifying cruelty." 38 As in the celebrated opening sections of Michel Foucault's Discipline and Punish, which appeared two years later, entitled "Of Torture," the violent infliction of pain is understood as a relative, rather than an absolute, wrong, to which the proper moral and political question is: compared to what alternative? Cruelty is not necessarily the worst evil society can inflict. ${ }^{39}$ But where Foucault located the transition from physical cruelty to panoptic control around the collapse of the old regime, Clastres inserted it quite simply in the space of difference between the primitive and the modern. Whether Clastres's argument is rooted in ethnographic observation or whether-again like Foucault's view-it is more fundamentally grounded in Nietzsche's contrast in The Genealogy of Morals between the cruel (but free) primitive and the humanitarian (but enslaved) modern, is an open question. Not surprisingly, Clastres saw no need to choose between these two alternatives: "If I had not reflected a bit on The Genealogy of Morals, I would have had more difficulty in writing [on torture]," Clastres explained in an interview. "Nietzsche, who probably knew nothing of and couldn't have cared less about the anthropology of his time (and rightly so), understood the problems of ... marking with infinitely more clarity than his contemporaries." 40 Fieldwork, therefore, eventually confirmed Nietzsche's prescient reversal of the

See G. Deleuze and F. Guattari, L'Anti-CEdipe: capitalisme et schizophrénie (Paris, 1972), chap. 3. Of the treatment of savages in this book, Clastres testified in a group interview in the debates around its publication that "Deleuze and Guattari write about Savages and Barbarians what until now ethnologists have not written.... It seems to me that ethnologists should feel at home in Anti-Oedipus." Praising their theory of the Urstaat, Clastres argued that they showed that "the state exists in primitive societies, even in the tiniest band of nomad-hunters ..., but it is constantly being warded off." He also praised their discussion of torture. Interview in La Quinzaine littéraire 143 (June 16, 1972), in English in Guattari, Chaosophy, ed. S. Lotringer (New York, 1995), 111, 112, 113.

38 Clastres, "De la torture dans les sociétés primitives," 188. For criticism that Clastres illegitimately compared primitive ritual to modern torture, see A. Margarido and M. Panoff, "De l'ethnologie comme torture des faits?," L'Homme 14/2 (1974), 139-42.

The prevention of cruelty has most famously been made the moral foundation and first principle of liberal modernity by Judith Shklar and, following her, Richard Rorty. See Shklar, Ordinary Vices (Cambridge, MA, 1984), chap. 1, Shklar, "The Liberalism of Fear," in N. L. Rosenblum, ed., Liberalism and the Moral Life (Cambridge, MA, 1989), and Rorty, Contingency, Irony, and Solidarity (Cambridge, 1989).

"Entretien avec Pierre Clastres," 21. 
progressivist fictions of his time, his praise of cruel primitive feasts and his hatred of his own modernity.

In his less developed work on primitive warfare (which he apparently planned at the time of his death to make his next book-length project), Clastres argued similarly. As in the case of torture, Clastres had vividly illustrated the bellicosity of the Guayaki in his chronicle. ${ }^{41}$ War presented another apparent difficulty for his overall thesis: not just because, like torture, it might undermine his idealization of the primitive but for the more fundamental reason that, by his own acknowledgment, chieftains took genuine power in the exceptional periods of wartime. ${ }^{42} \mathrm{He}$ insisted on the distinction, and the normativity of peace, against popular and even ethnographic fantasies about the permanence of war in the paleolithic. Reviewing the report of a Brazilian woman captured by the Yanomama Indians of Brazil and kept as a wife for two decades, Clastres remarked:

Since war is almost constantly present in the text ..., it leads us to ask: what impressions will the reader, even the slightly forewarned reader, have afterwards? There is reason to fear that these impressions will be unfavorable. What to think, indeed, of people who ceaselessly kill each other with relentless intensity, who do not hesitate to riddle with arrows today those who only yesterday were their best friends? And from then on, the illusions of the Noble Savage's peaceful habits collapse, since we only see war of literally everyone against everyone, the presocial state of man according to Hobbes. We should be clear: Hobbes' bellum omnium contra omnes does not correspond to an historic moment in human evolution any more than Rousseau's state of nature does... [L] et us not forget, without trying to reduce the sociological importance of war in these cultures, that the arrival of whites everywhere in America—North as well as South—led almost automatically to a doubling of hostility and war between tribes. ${ }^{43}$

Whether or not persuasive, this argument, of course, did not address the problem that even sporadic and intermittent warfare posed to Clastres's thesis. Towards what turned out to be the end of his life, Clastres confronted the challenge of occasional and temporary battle by claiming that war, for all its spilled blood

41 Clastres, Chronique des indiens Guayaki, esp. chap. 6.

42 In his initial article, Clastres touched briefly on the fact that American natives either had separate war and civilian chiefs or, in cases in which the roles coincided, restricted the chief's power at the conclusion of hostilities: "The model of coercive power is adopted, therefore, only in exceptional circumstances when the group faces an external threat." Clastres, "Échange et pouvoir," 30. His thought later shifted on this point; see below, n. 70.

43 Clastres, "Une ethnographie sauvage," L'Homme 9/1 (1969), 58-65, rptd in Recherches d'anthropologie politique, chap. 2, in English in The Archeology of Violence, 35-6. The essay is a review of H. Valero and E. Biocca, Yanoàma: The Narrative of a White Girl Kidnapped by Amazonian Indians, trans. D. Rhodes (New York, 1969), a book that appeared in France in 1968 . 
and necessary commanders, nevertheless played a homeopathic function: a little violence and leadership keep more away. Rejecting the theses that war is natural (Hobbes's thesis, supposedly confirmed by accounts of savages) and economic arguments that war arises over scarce resources or because of a breakdown of exchange, Clastres proposed the need for a political interpretation that did justice to the integrality of war to primitive life without making them simply equivalent. ${ }^{44}$ Noting that the warfare as a rule occurred between separated groups, and not as indiscriminate mayhem, Clastres proposed this solution to the problem:

[I]f there is indeed a profound relationship between the multiplicity of sociopolitical entities and violence, one can only understand this link by reversing the habitual order of their presentation: it is not war that is the effect of segmentation, it is segmentation that is the effect of war. It is not only the effect, but the goal: war is at once the cause of and the means to a sought-after effect and end, the segmentation of primitive society. In its being, primitive society wants dispersion. ${ }^{45}$

And for this primitive will to sociological dispersion, Clastres already possessed an explanation. It was only on condition of membership in bounded entities that primitive men could preserve their peculiar institution of power, their rejection of hierarchy, and their self-immunization against statehood. "Primitive society is a community that assures control of its territory in the name of the Law guaranteeing its non-division," Clastres maintained. "The territorial dimension already includes the political in that it excludes the other." ${ }^{46}$ Given the assumption of their inevitable encounter, individual units will necessarily enter battle, because each is structurally constituted to exclude all of the others. "The unification of partial We's into a meta-We, the elimination of the difference unique to each autonomous community would abolish the distinction between the We and the Other, and primitive society itself would disappear," Clastres explained. ${ }^{47}$ Clastres's view of savage politics is thus strikingly, albeit unintentionally, like that of Carl Schmitt: founded on a root distinction between friend and foe, as the essence of the political. But-I suppose Clastres would say-primitive

44 Clastres surveys alternative prior interpretations of war, including that of Lévi-Strauss, in "L'archéologie de la violence," 143-52. Hobbes argued: "It may peradventure be thought, there was never such a time, nor condition of warre as this; and I believe it was never generally so, over all the world: but there are many places, where they live so now. For the savage people in many places of America... have no government at all and live at this day in that brutish manner, as I said before.” T. Hobbes, Leviathan, ed. R. Tuck (Cambridge, 1996), 88.

45 Clastres, "L'archéologie de la violence," 153. On the requirement of sharp boundaries and limited size, cf. "Entretien avec Pierre Clastres," 23.

46 Clastres, "L’archéologie de la violence," 156.

47 Ibid., $157-8$. 
friends are all equal, they have a pact to refuse the statist division of society into rulers and ruled, where Schmitt revives the logic of friend and foe within that state-based logic, where hatred of foes is not weighed in the balance against the absence of hierarchy. In his acknowledgment of war as a structural necessity, Clastres insisted that primitive men gain the compensation of a society without division. ${ }^{48}$ To avoid war, Hobbes chose the state. But, misunderstanding the role of violence in savage lands, he never considered the alternative choice. To avoid the state, savages chose war.

Especially in light of the torture and war it requires to avoid the dialectic, the primitive world's implicit superiority becomes clear only in a survey of Clastres's thought about the state-based alternative to it. Quite simply, Clastres assimilated rival visions of the state to its totalitarian climax and judged them in light of it. In what counts as his major persisting allegiance to Hegel and his Marxist, Leninist, and Stalinist followers, it is as if any state is embittered by the foretaste of its epitome, by its failure to wither away over time and, even under conditions of revolution, to always become yet stronger. In this way, Clastres's search exterior and prior to the dialectic reflects a continuing allegiance to Hegel's script: a tacit agreement that, once it begins, there lies nothing outside of it, that it will rush towards its conclusion, and gather even what seems to oppose it-in Hegel's version of theodicy - to its purpose.

Occasionally, Clastres suggested more nuance. His fundamental distinction between societies with and without a state, he once wrote,

does not mean, of course, that all societies with a state are identical to one another: we could not reduce to a single type the diverse historical configurations of the state, and

48 In a related essay, Clastres addressed the separate problem of a relatively permanent and stable warrior class and ethos in some primitive societies. Though the warrior class and ethos are necessary because of the structural requirement of war in primitive society, they also threaten to be a self-defeating solution: the imperative of war might introduce social class and (permanent) leadership. Clastres argued, however, that the primitive society compensates for this danger: the warrior ethos implants what amounts to a death-wish in those who are animated by it. In his words: "There is an exchange between society and the warrior: prestige for exploit. But in this confrontation, it is society, mistress of the rules of the game, that has the last word: for the ultimate exchange is that of eternal glory for the eternity of death. Ahead of time, the warrior is condemned to death by society: no joy for the savage warrior, only the certainty of sorrow. But why? Because the warrior could cause the sorrow of the society by introducing the germ of division... [The exchange is] the undivided social body's life for the warrior's death." Clastres, "Malheur du guerrier sauvage," 193. He forecast this result in Clastres, "La Société contre l'État," the last (previously unpublished) essay in the book of the same name; English edn, 209-10. 
nothing allows us to confuse the archaic despotic state, or the liberal bourgeois state, or the totalitarian fascist or communist states. Being careful, then, to avoid this confusion which would prevent, in particular, an understanding of the radical novelty and specificity of the totalitarian state, we shall note that a common property makes societies with a state as a whole different from primitive societies. ${ }^{49}$

This willing distinction between forms of the state, however, is evidently compatible with a dialectical view of their interrelationship as successive "stages" of history. Whether or not he held this exact view, Clastres spoke often of the pathology of all forms of the state; and there is no way to understand the pathos of his search for an alternative except on the assumption that he believed that the totalitarian state merely epitomized the more general object of his condemnation. Nothing else than the fixation on totalitarianism can explain the recommendation that Clastres offered in an interview: "Don't be fooled by appearances ... The machine of the state, in all Western societies, is becoming more and more statist, which is to say that it will become more authoritarian ... with the deep support of the majority." He added: "The statist machine is heading towards a kind of fascism, not the fascism of a party, but an interior fascism." Everyone sought the authority to command, even those who promised to use the state in the name of freedom..$^{50}$ The varieties of modern politics were simply variations on the same evil theme.

The grounds for Clastres's exaggerated, and monomaniacal, hatred of the state are partly biographical. Many ex-communists have felt it. But Clastres took the fanatical suspicion of the state, familiar among some ex-communists, to an altogether new level of theoretical sophistication. And then there is the circumstance of the 1970s in which he wrote, the years of Alexander Solzhenitsyn's Gulag Archipelago, and the widespread conviction in France that the rejection of totalitarianism counted as the beginning of political wisdom. For most, the mood that made his theory possible and popular has disappeared (though not without leaving behind a legacy). But it is worth considering more seriously one of his reasons for this grim and fatalistic perception of the total control of the world that the state's unstoppable administrative extension would eventually cause.

Some of Clastres's most powerful writing dealt with the extinction of the very tribes he had once studied, and others like them. Clastres's essays suggest that

49 Clastres, "La question du pouvoir dans les sociétés primitives," Interrogations 7 (1976), 3-8, rptd in Clastres, Recherches d'anthropologie politique, chap. 6, and in English in Clastres, The Archeology of Violence, 88; cf. Clastres, "De quoi rient les Indiens?," Les Temps modernes 253 (1967), 2179-98, rptd in Clastres, La Société contre l'État, chap. 6, in English in Clastres, Society against the State, 152.

"Entretien avec Pierre Clastres," 24-5. 
he felt himself to be one of the last witnesses to the only alternative humanity had once enjoyed to the state and to the punishing force the victorious dialectic imposed on its rival as it neared its acme. When Clastres returned from one of his initial missions, in 1967 , he noted to the French anthropological community his "impression that the final decline [of the Indians] is occurring now. The cries of alarm of thirty years ago were perhaps premature, but now they risk being too late." Observing that in the prior decade more tribes had disappeared than during the previous four, he concluded wistfully: "Soon, there will be no more Indians." 51

In the years after Clastres's return came reports of genocide, providing a macabre confirmation of his prediction. "Throughout these past years," Clastres wrote then, "the massacres of Indians have been denounced in Brazil, Colombia, and Paraguay. Always in vain." ${ }^{2}$ The few survivors of genocide, Clastres noted in an anti-Hegelian spirit in the conclusion of his ethnographic masterpiece, were like "unclaimed objects; hopelessly forced to leave their prehistory, they had been thrown into a history that had nothing to do with them but to destroy them." 53 Even when they were not physically killed, Clastres suggested in his most reflective piece on the subject of tribal annihilation, they were the subject of "ethnocide" (then a recent coinage). ${ }^{54}$ Clastres suggested that ethnocide reflected a certain optimism in the confrontation with difference; unlike genocide, which is committed to difference's eradication, ethnocide treated it as reversible rather than unsalvageable. But rather than locating the causes in Western ethnocentrism, Clastres insisted that the explanation for it had to lie elsewhere; after all, all cultures are ethnocentric_-even the Guayaki, whose name for members of their own tribe is "Aché" or "persons." 55 It followed that ethnocide, a local phenomenon, required more than ethnocentrism, a universal one. Its explanation demanded inclusion of the only variable absent among the savages but present among the civilized: the state. "Ethnocide," Clastres averred, "results in the dissolution of the multiple into one. Now what about the state? It is, in essence, a putting into play of centripetal force, which, when circumstances demand it, tends toward crushing the opposite centrifugal forces." ${ }^{56} \mathrm{He}$ appealed to the French example

51 Clastres, "Mission au Paraguay et au Brésil," 108.

52 Clastres, "De l'ethnocide," Encyclopedia universalis (Paris, 1974), 2826-9, rptd in Clastres, Recherches d'anthropologie politique, chap. 4, in English in Clastres, Archeology of Violence, 44.

53 Clastres, Chronicle of the Guayaki Indians, 345.

54 Cf. R. Jaulin, La paix blanche: introduction à l'ethnocide (Paris, 1970), Jaulin, ed., Le Livre blanc de l'ethnocide en Amérique (Paris, 1972), and Jaulin, ed., La Décivilisation: politique et pratique de l'ethnocide (Brussels, 1974).

55 Clastres, "De l'ethnocide," 46.

56 Ibid., 47-8. 
of state centralization, notably in the era of the French Revolution and the nineteenth century when differences were eliminated in the service of state-based identity. Did anything remain in France of village life? Only "folkloric spectacle destined for the consumption of tourists," Clastres argued. ${ }^{57}$ Ethnocide became spectacular when externalized abroad, but it began at home. It was thus the state, and no other factor, that Clastres could single out as the ultimate culprit for ethnocidal practices. Clastres appealed to economic factors, for once, to explain what differentiated some states from others in the intensity of their imperialism. The modern industrial system, east and west, in the Soviet bloc or the free world, is "the most terrifying machine of destruction," Clastres wrote. "Races, societies, individuals: space, nature, seas, forests, subsoils: everything is useful, everything must be used, everything must be productive, with productivity pushed to its maximum rate of intensity. This is why no respite could be given to societies that left the world to its original, tranquil unproductivity." 58 Though his allegiance to Marx ended unceremoniously, and though his affection for Heidegger waned, Clastres's vociferous hatred of capitalism and instrumentalism never wavered.

Did he hit, nevertheless, on the cause of the bloodshed? The reason why the last alternative to the dialectic appeared to have been crushed in his own lifetime? For on this point, nobody should mistake or minimize the source of his outrage. Stateless societies could not resist the state; and there was blood on the slaughterbench. "Presently, in all South America, the last free Indians are succumbing," Clastres concluded. "The change will be carried out to the end; it will be carried out until there is nothing left to change." 59

In leaving Hegel's teleology behind, did Clastres then regress to Rousseau's primitivism? In spite of his repeated denials over the years, there is good reason to believe it. Aside from the many other parallels with Rousseau's Discourse on the Origins of Inequality - the freedom, equality, and happiness of the savage not least-there is Clastres's recognition in Society against the State of the need for a story of how the disaster occurred and, with the dialectic's beginning, how the statist order took root. His answer, like that of Rousseau, is that there must have occurred "various chance happenings" or even a single "fatal chance occurrence that, for the common good, ought never to have happened." 60 More mournfully even than Rousseau, Clastres obsessed about the reasons that the history of

57 Ibid., 49 .

58 Ibid., 50.

59 Ibid., 51.

60 J.-J. Rousseau, The Basic Political Writings, trans. D. Cress, intro. P. Gay (Indianapolis, 1987), 59, 65 . 
civilization might have begun. But in this inquiry he claimed to walk not in the footsteps of Rousseau but of a different early modern Frenchman, one who had made the rise of the state the focal problem of his thought: Étienne de la Boétie.

Michel de Montaigne's close associate, the subject of his essay "Of Friendship," La Boétie played an interesting but unremarked role in the political discourse of France in the 1970s - perhaps not surprisingly, in a decade living in the aftermath of a failed hope for utopian freedom and awakening to the reality of continued servitude. At this important moment, Lefort's and Clastres's followers Miguel Abensour and Marcel Gauchet published a new edition of La Boétie's Discourse on Voluntary Servitude, appending to it commentaries by their mentors. ${ }^{61}$ What is interesting is the fixation of Clastres's reading on the problem of the origins of statist domination, which made a contrast with other possible readingsincluding those offered by others at the time.

La Boétie's heroism, for Clastres, is not surprisingly a precursor to his own. It is the ability, from within history, to resist its totalistic claims, to see the existence of a lost alternative before it. "If I can be surprised that voluntary servitude is a constant in all societies," Clastres remarked, in a sense illustrating his identification with his predecessor,

it is, of course, because I imagine the logical possibility of a society that would not know voluntary servitude. La Boétie's heroism and freedom: precisely this smooth transition from History to logic, precisely this gap in what is most naturally obvious, precisely this breach of the general conviction that we cannot think of society without its division between the dominating and the dominated. The young La Boétie transcends all known history to say: something else is possible. ${ }^{62}$

Asking the question is what mattered: "[W]hat misfortune so denatured man," La Boétie had wondered, "only born in truth to live freely, to make him lose the memory of his first existence and the desire to retrieve it?" A question Clastres read as a revitalizing affirmation: "What he discovers, by slipping out of History, is precisely that the society in which people want to serve the tyrant is historical, that it is not eternal and has not always existed, that it had a date of birth and something must have happened, necessarily, for men to fall from freedom into servitude." La Boétie first made the thrilling discovery that the "birth of History, this fatal rupture," is an explanatory problem. It is also a normative puzzle. For it "never should have happened." ${ }_{3}$

61 E. de la Boétie, Le Discours de la servitude volontaire, ed. M. Abensour, intro. Abensour and M. Gauchet (Paris, 1976). Abensour later edited the proceedings of a conference in Clastres's memory: see above, n. 4.

62 Clastres, "Liberté, malencontre, innomable," in ibid., rptd in Clastres, Recherches d'anthropologie politique, chap. 7, in English in Clastres, The Archeology of Violence, 94.

63 Clastres, "Liberté, malencontre, innomable." 
Revealingly, Clastres also praised La Boétie-in effect if not in intent for anticipating him-for placing such a singular emphasis on the great fall from equality, for such a wise refusal to make fine distinctions between the series of post-lapsarian authorities. "The result of this split between free society and slave society," Clastres summarizes,

is that all divided societies are slave societies. That is to say, La Boétie does not make distinctions within the ensemble constituted by divided societies: there is no good prince with whom to contrast the evil tyrant. La Boétie is scarcely concerned with studies in character. What does it really matter whether the prince is kind or cruel: whatever the case, is it not the prince whom the people serve? ${ }^{64}$

In this way, La Boétie saw in advance the genuine authority for the radical assimilation of all statist societies to one another. He saw that "all relationships of power are oppressive, that all divided societies are inhabited by absolute evil," and uncovered the "pure logical opposition" that brings into view the "evil that gangrenes the entire divided social body." ${ }^{\prime 6}$ La Boétie's insight allowed Clastres to throw his occasional caution to the wind and indulge his secret belief that the seed of totalitarianism is in some ways equivalent to its fulfillment: " $[\mathrm{O}]$ nce the freedom that naturally governed the relations between equals has been lost, absolute evil is capable of anything; there is a hierarchy of the worst, and the totalitarian state in its various contemporary configurations is there to remind us that however profound the loss of freedom, it is never lost enough, we never stop losing it."66

Clastres's appropriation of La Boétie, finally, also excused a glaring lapsus in his own project. He had no good answer to the problem of how the state arose. Referring to it only as "misfortune," La Boétie, Clastres wrote, had "no idea" of how to solve this problem either. ${ }^{67}$ And, like Clastres, La Boétie (on Clastres's reading) excused himself from providing any solution to voluntary servitude, restricting himself to mourning that it had arisen. "[T]here is a point of no return," Clastres interpreted La Boétie as saying, and "such a passage can only take place one way: from the non-state to the state." ${ }^{68}$ Actually, the reality is slightly more complex. Clastres entertained many hypotheses through his life about what factors might have given rise to the state. He did so, he noted at one point, because "perhaps the light cast upon the state's moment of birth will also illuminate the conditions of the possibility (realizable or not) of its

\footnotetext{
64 Ibid., 95 .

65 Ibid.

66 Ibid., 97.

67 Ibid., 98.

68 Ibid., 99.
} 
death." 69 Of course, given the fear and loathing of the state at this moment in French political thought, Clastres did not pose the question of its origins alone. Initially, he considered the hypothesis that the chief's empowerment in war might somehow escalate into political leadership. But by the end of his career, he denied that war required any kind of leadership. ${ }^{70}$ Nevertheless, notes he left at the time of his death suggest that he planned to return to the problem of the war chief. ${ }^{71} \mathrm{He}$ also flirted with a demographic explanation for the rise of the state: if primitive communities had to remain small and bounded, as a condition of avoiding the state, then it seemed possible for the failure of self-regulating growth to allow the fateful break to occur. ${ }^{72}$ Elsewhere, he appeared to briefly admit the possibility that the "confusion" of the state could arise for economic reasons, if "the activity of production is diverted from its initial goal, when, instead of producing only for himself, primitive man also produces for others."73 Even then, however, he insisted that this event could occur only after the state arose, with economic following upon political inequality. "[T]he emergence of the State determines the advent of classes." ${ }^{4}$ For this reason, the class struggle does not occur before the beginning of history. Accordingly, Clastres fulminated early and late in his career against Marxists, from Friedrich Engels to the new wave of Marxist anthropologists, who explained the origins of the state as dependent on the more fundamental factor of economic class. ${ }^{75}$ Finally, Clastres considered whether the state could somehow have been brought about by the activity of religious prophecy. ${ }^{76}$ Generally speaking, however, Clastres felt free to refer to the

69 Clastres, "La question du pouvoir dans les sociétés primitives," 92.

70 Clastres, "Malheur du guerrier sauvage," 170 : "[C]ontrary to an opinion that is as false as it is widespread (that the chief has no power, except in times of war), the warrior leader is at no moment of the expedition (preparation, battle, retreat) in a position—should such be his intention-to impose his will ... [F] reedom is not canceled by the will for victory, even at the price of operational efficiency."

71 In a note by Libre's editors, appended to ibid., 200.

72 See Clastres, "Indépendance et exogamie: structure et dynamique des sociétés indiennes de la forêt tropicale," L'Homme 3/3 (1964), 67-87, rptd in Clastres, La Société contre l'État, chap. 3, in English in Society against the State.

73 Clastres, "La Société contre l’État," 198.

74 Ibid.

75 See Clastres, "L’Économie primitive," and esp. “Les Marxistes et leur anthropologie." The locus classicus of the Marxist account of the origins of the state is in Engels's work, The Origin of the Family, Private Property, and the State (1884). For the Marxist counter-attack on Clastres, see J.-L. Amselle, ed., Le Sauvage à la mode (Paris, 1979).

76 Clastres's wife made this the subject of her own book-length study in the period. See H. Clastres, La Terre sans mal: le prophétisme tupi-guarani (Paris, 1975), in English The Land-Without-Evil: Tupí-Guaraní Prophetism, trans. J. G. Brovender (Urbana, IL, 1995). 
emergence of the state as the "mystery (perhaps a temporary one) of the origin." La Boétie's proto-Rousseauian picture of "mischance" confirmed the mystery. But there is little doubt that it may have mattered most for Clastres that La Boétie anticipated Nietzsche, who referred to the origins of the state as "not a gradual or voluntary" event but rather "a break, a leap, a compulsion, an ineluctable disaster that precluded all struggle." 78 From this inexplicable catastrophe, what recovery?

Clastres's romanticized vision of society against the state not only failed to fulfill the primary need of his (but not only his) time-a theory of democratization in which society and state are complementary-but imposed an obstacle to its fulfillment. For this reason, it played both a role in and is illustrative of the origins of three problematic paths out of the 1970 s which many have pursued.

First, the most evident political implication of Clastres's arguments-though at the time and since they have proved attractive to anarchists - is a kind of paralyzed mourning. It intended to break fundamentally with Marxism, but Clastres's work nevertheless shared the implication of Marxist theory that the institutionalization of freedom is to be found anywhere but through reform of the lineaments of freedom in what already exists. It ruled out Marxist utopianism as excessively continuous with the present statist order, only to replace it with primitivist nostalgia or exoticist longing. The past and the other replaced the future. Encouraging the mind to wander to other places and other times, Clastres's work did not encourage a nuanced appraisal of the prospects of reform in the here and now. In this way, Clastres's anti- but not yet genuinely post-Marxist perception that the state in all its forms is corrupted by a "neo-theology of history with its fanatic continuism" prevented him from presenting a viable stance for those who are unable to escape the circumstances of Western modernity - which is to say, in a globalized world, everyone. ${ }^{79}$

But-second and third-for those dissatisfied with his resignation, Clastres's work further helped to create a poor but fateful alternative just beyond the

77 Clastres, "La Société contre l'État," 205.

78 Nietzsche, The Genealogy of Morals, Second Essay, § 17. Clastres's engagement with La Boétie prompted an important reply by Pierre Birnbaum, multiplying the discussions of La Boétie in the 1970s: P. Birnbaum, "Sur les origines de la domination politique: A propos d'Étienne de la Boétie et de Pierre Clastres," Revue française de science politique 27/1 (1977), 5-21, with a response from Clastres, "Le retour des Lumières," ibid., 22-8, rptd in Clastres, Recherches d'anthropologie politique, chap. 9, in English in Clastres, The Archeology of Violence. Birnbaum's essay is rptd in Birnbaum, Dimensions du pouvoir (Paris, 1984). 
limits of his own position. Either it provided a stepping-stone to the neo-liberal position-which as a matter of fact, in the form of Marcel Gauchet's work, developed in part out of Clastres's philosophy. ${ }^{80}$ Clastres's poisoned view of the state left a legacy in the view that the danger of totalitarianism lurking everywhere in the modern world makes the security of freedoms against the state the only realistic achievement in a politics without illusions. Or, when it did not devolve in this manner into a complacent neo-liberalism, Clastres's theory helped give rise to the one-sided belief on the left that democracy is primarily a matter of civil society rather than also the imagination of a reformed state; put differently, it prompted the illusion of the programmatic separability between society and the state, ignoring the necessary role of the state in the development and promotion of a free and vibrant civil society outside it.

No more, after Clastres and his post-Marxist moment, would most indulge the disastrous illusion that the road to freedom runs through the violent seizure of the apparatus of the state. With the historical moment in French political thought through which he lived, that he shaped as it shaped him, Clastres helped to fundamentally change prevalent beliefs about the likely forms in which freedom is to be institutionalized. In this way, Clastres's work played an important role in the rise in contemporary theory of the importance of civil society. Marginal to traditional political argumentation-except that of Tocqueville, unsurprisingly revived at precisely this moment-it became central to liberal understandings of the nature of a free society as well as the favorite place to look for hope of those reforming leftists choosing to make the journey, as the title of a book by Andrew Arato had it, "from neo-Marxism to democratic theory." ${ }^{81}$ But Clastres's cuvre, and the rebirth of civil society of its moment, were often too strongly marked by the opposition to totalitarianism which animated them negatively like a paranoid obsession. They not only helped prepare the way for the emphasis on civil society, but conditioned the way in which its importance in the overall political realm came to be understood: in recklessly assimilating the state in its different possible forms to the singular evil of the totalitarian state, Clastres's work not only forced an excessive burden onto civil society alone as the locus of freedom; it also neutralized a theory of the state, condemned and feared in all its forms, that could complement and come to the aid of civil society.

80 See S. Moyn, "Savage and Modern Liberty: Marcel Gauchet and the Origins of New French Thought" (forthcoming), for a full bibliography of Gauchet's revealing homages to and commentaries on Clastres's work.

81 A. Arato, "Civil Society against the State: Poland, 1980-81," Telos 47 (1981), 23-47, rptd in From Neo-Marxism to Democratic Theory: Essays on the Critical Theory of Soviet-Type Societies (Armonk, 1993); or J. Keane, ed., Power of the Powerless: Citizens against the State in Central-East Europe (Armonk, 1985). 
And yet, the incandescence of his mind and the brilliance of his rhetoric may not permit so easy and comfortable a negative verdict on his position, for to read the ensemble of his writings is to confront the uncompromising positiontragic but possibly true-that the disaster has already occurred, the dialectic is ongoing, and the state has won and, far from creating the conditions for a free and equal society, has decisively ruled that society out. A remnant of the Guayaki now have their own web presence, where they-or, more accurately, a Californian venture operating in their name-advertise their own Yerba Maté tea, "a powerful rejuvenating beverage grown in its native rainforest environment for premium quality and flavor," thus demonstrating the possibilities of "market-driven conservation" that, powered by "conscious consumers," promotes "harmony with indigenous cultures and their environment." Thirty-four families, living on 2,500 acres,

are able to farm using their traditional methods, and practice their traditional ceremonies. Individuals from the community have the option to participate in the growth, harvesting and production of yerba maté to earn additional personal income if they desire. Together with local Paraguayans, they produce Guayakí Yerba Maté which generates income to provide upgrades to housing facilities, medicines for the health clinic, and supplies for the school ...82

Never mind that the Guayaki were just a few decades ago a nomadic, huntergatherer rather than a stationary, agricultural tribe: they are on the way to the state and the market, thanks to the imposition of both. "A thousand years of wars, a thousand years of celebrations!" So Clastres wrote at one point, expressing what he hoped the remnant of savagery fighting for survival against an ever-advancing civilization might still enjoy.

Is this pious? I'm afraid so. They are the last of the besieged. A mortal shadow is being cast on all sides... And afterwards? Perhaps we will feel better once the final frontier of this ultimate freedom has been broken. Perhaps we will sleep without waking a single time ... Someday, then, oil derricks around the chabunos, diamond mines in the hillsides, police on the paths, boutiques on the riverbanks ... Harmony everywhere..$^{83}$

Clastres did not live long enough to observe, to those still troubled in the dark night of the dialectic's fulfillment, that a cup of Guayaki tea will not help them drift into sleep. It is a stimulant.

82 See http://www.guayaki.com.

83 Clastres, "Le dernier cercle," Les Temps modernes 298 (1971), 1917-40, rptd in Recherches d'anthropologie politique, chap. 1, and in English in The Archeology of Violence, 27. 